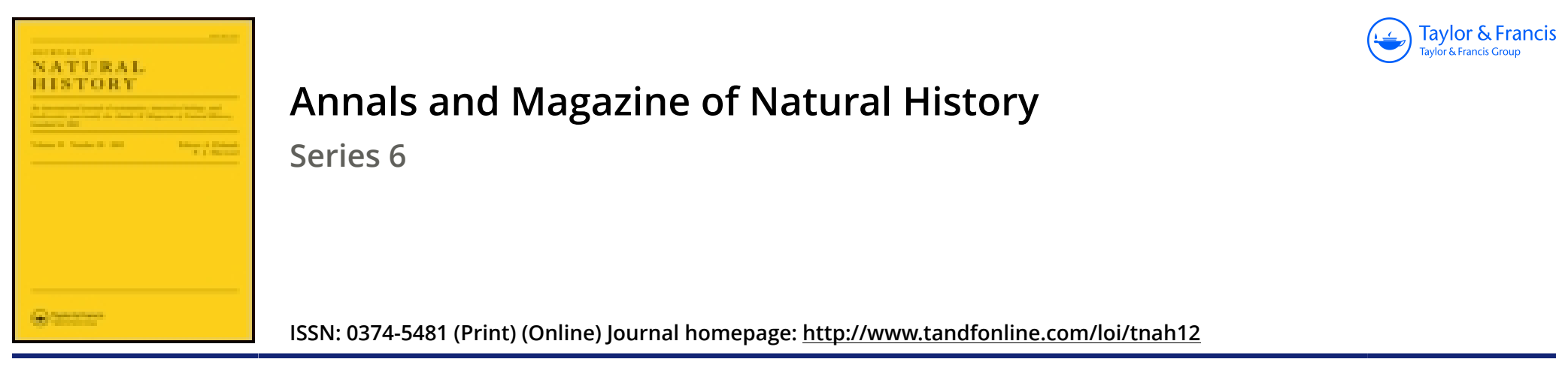

\title{
LI.-On two new species of birds from Kina Balu Mountain
}

\section{R. Bowdler Sharpe F.L.S. F.Z.S.}

To cite this article: R. Bowdler Sharpe F.L.S. F.Z.S. (1889) LI.-On two new species of birds from Kina Balu Mountain , Annals and Magazine of Natural History, 3:17, 423-424, DOI: 10.1080/00222938909460361

To link to this article: http://dx.doi.org/10.1080/00222938909460361

曲 Published online: 09 Oct 2009.

Submit your article to this journal \lceil

Џll Article views: 1

Q View related articles $\square$

Citing articles: 1 View citing articles $\square$ 
to the measurements already given it may be added that the greatest breadth of the arms is 50 millim. It is not a little remarkable that a Luidia should have attained to so great a size without any injury to its arms, and it is certainly to the credit of $M$. de Robillard that he has succeeded in safely sending so large and fragile a specimen safely to this country.

In the large central mouth there were found the remains of a Stomopneustes variolaris; a number of still uninjured or undigested spines suggests that the starfish had not quite relished the prickliness of his prey; on the other hand, we may suppose that it was necessary to acquire a quantity of carbonate of lime by some means or other, and even at the expense of some personal inconvenience.

The largest British specimens of Luidia as yet in the British Museum measure respectively 425 and 426 millim. in spread, have the disk 53 and 69 millim. in diameter, and the longest arms 223 and 220 millim.

Of other large specimens of which I have heard from Professors M'Intosh and Herdman, and Mr. W. Percy Sladen none are credited with a wider spread than 18 inches, and there appears to be no record of any fossil species attaining to any such large size *.

What interest there is in this communication lies in the announcement of the gigantic size of a starfish; I have nothing to add to the, as usual, complete account of the species which we owe to $M$. de Loriol †.

\section{LI.-On two new Species of Birds from Kina Balu} Mountain. By R. Bowdler Sharpe, F.L.S., F.Z.S.

Mr: John Whiteriead, who is about to travel in Southeastern Africa, has asked me to describe a new species of Barbet which he discovered on Mount Kina Balu, in Northern Borneo. I at first thought it might represent one of the many phases of plumage through which Megaloma mystaco. phanus passes before it becomes fully adult. A close exami-

* An Asterias glacialis in the Museum has a spread of 450 millim., with a disk of 55 millim. diameter, and the greatest arm-length 220 millim. Mr. R. L. Spencer, of Guernsey, tells me he has seen specimen.s a little over 18 inches.

+ Mém. Soc. physs. et d'hist. nat. de Genève, xxix. no. 4, p. 72. 
nation, howcver, convinces me that it is a distinct species, different from any eastern Barbet yet known.

I propose to call it

\section{Cyanops monticola, sp. n.}

o acl. Prasino-viridis, alis et cauda saturatioribus; fronte et loris smaragdinis, sincipite et pilei lateribus læte cyaneis ; plaga magna verticali scarlatina usque ad nucham producta; facie laterali et regione parotica pallide cyaneis, fascia supraparotica smaragdina; genis gulaque pallide flavis, hac infra cyanescente et macula scarlatina ad latera juguli posita ornata; præpectore et corpore reliquo subtus pallide smaragdinis.

Long. tot. $9 \cdot 0$, culm. $1 \cdot 15$, alæ $3 \cdot 9$, caudæ $2 \cdot 5$, tarsi $1 \cdot 05$ poll. Angl.

The nearest ally of this species is Cyanops incognita, Hume, from Tenasserim. It differs, however, from that species in its larger size, in the absence of the black facial stripes and red loral spot, as well as in the colour of the throat, which is bright bluish green in C. incognita.

I take this opportunity of observing that the Chlorura which I described in the 'Ibis' for 1887 (p. 453) as C. hyperythra of Reichenbach turns out to be distinct from that species, having the rump and upper tail-coverts like the back. I propose to call it Chlorura borneensis.

\section{LII.-The Polyzoa of the St. Lavrence: a Study of Arctic} Forms. By the Rev. Thomas Hincks, B.A., F.R.S.

[Plate XXI.]

[Continued from vol. i. p. 227.]

Suborder * Ch EIL OST OM A t A.

Family Escharidæ (part.), Smitt.

Rhamphostomella, Lorenz.

Rhamphostomella, Lorenz, Bryozoën von Jan Mayen, gesammelt von Dr. F. Fischer, Arzt der österreichischen Expedition auf Jan Mayen, bearbeitet von Dr. Ludwig Lorenz, 1886.

This genus has been instituted by Lorenz for a group of species which is very characteristic of the Aretic and Northern

* In the first part of this Report ("Annals' for March 1888, p. 215, line 12 from the top) for "Subclass" read "Suborder." 